\title{
Online Project based Instruction in English Language Learning: Theory and Practice ${ }^{1}$
}

\section{Dr. Hasnaa Sabry Abdel-Hamid Helwa} Lecturer at Department of Curriculum and TEFL Instruction- Faculty of Education- Benha University-Egypt Dr.Shaimaa Sabry Abdel-Hamid Helwa Lecturer at Department of Mass Communication-Faculty of Specific Education- Benha University- Egypt

\section{Abstract}

he aim of this research paper is to investigate the
effect of online project based instruction on
English language learning. It provides theoretical background about online project based learning, and then clarifies how it can be used for developing English language. Project-based learning-powered by contemporary technologies is a strategy certain to turn traditional classrooms upside down. When students learn by engaging in real world projects, every aspect of their experience will change. The teacher's role shifts, he or she is no longer the content expert and student behavior also changes. Instead of following the teacher's lead, learners pursue their own questions to create their own meaning, even the boundaries of the classroom change. Teachers still design the project as the framework for learning, but students may wind up using technology to access and analyze information from all corners of the globe.

Key words: Online project, Language learning.

\section{Introduction}

Language is one of the most important areas of human development. It is a vital tool for communicating thoughts and ideas. Nowadays, learning English has become a necessity all over the world. It requires mastering of the four language skills; listening, speaking, reading and writing. The skills are related to each other by two parameters: the mode of communication: oral

1 Paper Presented to the 3rd International Conference (The Future of Teacher's Preparation and Qualification in the Arab World) in Faculty of Education (October 6th University) 23 - 24 April 2017 
skills (listening and speaking) and written skills (reading and writing). The direction of communication: receptive skills (listening and reading) and productive skills (speaking and writing) (Alodwan and Ibnian, 2014 ,Bagheri and Faghih,2012).

Therefore, the ways how English is taught and learnt are now undergoing some adjustments in order to keep up with the advancement of information and communication technology (ICT). Two decades ago, for example, online communication through internet was not a common view in an English classroom. But now, such a learning activity may easily be spotted in most modern classes (Marwan,2015).

The idea of incorporating computer technology in EFL instruction has always been the focal point of discussions. It leads to significant changes in teachers' approaches, methodologies and strategies to teaching foreign language. Thus, using technology to support teaching and learning makes it possible to use powerful methodologies such as cases, projects, and problems that are meaningful, holistic, and representative of authentic or real-world tasks. Their use requires teachers to design and develop learning tasks and activities that enhance the classroom curriculum. Several learning theories and teaching strategies can create the conditions for active learning in the classroom .These include anchored instruction, case-based learning, cooperative learning, inquiry learning, problem-based learning, and project-based learning. Teachers can use a projectbased approach to create learning activities in which students use the information resources on the Internet to construct knowledge. With such an approach students work on projects that are meaningful activities situated in contexts that simulate real-world problems and conclude with final products that present solutions to the problems (Alsied and Pathan, 2013,Mills, 2006, Thitivesa and Essien, 2013).

Project-based learning-powered by contemporary technologies is a strategy certain to turn traditional classrooms upside down. When students learn by engaging in real world projects, every aspect of their experience will change. The 
teacher's role shifts, he or she is no longer the content expert and student behavior also changes. Instead of following the teacher's lead, learners pursue their own questions to create their own meaning, even the boundaries of the classroom change. Teachers still design the project as the framework for learning, but students may wind up using technology to access and analyze information from all corners of the globe. Connections among learners and experts can happen in real time. That means new kinds of learning communities can come together to discuss, debate, and exchange ideas (Krauss and Boss, 2013).

The project-based approach with learner-centered activities should assist learners in developing thinking skills. Through project-based approach learners will develop both their right and left brains, with the left functioning to memorize, analyze, identify and the right functioning holistically to synthesize ethics and creativity. Learners learn according to their interest, aptitude, and potential, making them learn enthusiastically. Learners' thinking competence is developed, leading them to possess learning strategies and become a future researcher and life-long learner. The project helps to create work outcomes that are evidence of sustainable and in-depth understanding. It also trains learners to perform thinking processes involving steps in the scientific method. It can be used to build knowledge or new inventions according to the knowledge building theory, with the emphasis on knowledge finding and discovery by an inquiry method (Supadol,et al,2014).

Project based instruction is important in the learning process. It builds on individual strengths, and allows individuals to explore their interests in the framework of a defined curriculum. It is holistic in nature and incorporates the principles of providing challenging and complex work and encourages cooperative learning. It also lends authenticity to learning. It is a teaching method that has different characteristics than conventional. The ideology of Project based instruction lies in learning by doing (Dewey; 1900s) that also reflects constructivism theory. Project based instruction is the use of 
classroom project in learning and assessment in order to facilitate students in constructing their meaningful idea and knowledge to the real world. It is centered on the learners and affords learners the opportunity for in depth investigations of worthy topics. Project is defined as assignment which aims at having students produce a product. With project based instruction, students are encouraged to explore their own interests and make connections to the world beyond school. It is a student-driven, teacher-facilitated approach to learning (Chikita, Nyoman and Wayan ,2013).

Mills (2006) and Wengerd (2009) indicate that Project based instruction is a student-centered way of teaching that follows many of the constructivist and social constructivist ways of thinking. It engages students in deeper levels of thinking, comprehension, and interpretation. It also prepares students for the real world through active process that teaches critical thinking, problem solving, teamwork, negotiation skills, technology, and responsibility for one's own learning. It involves real-life simulations, critical thinking, goal setting, problem solving, and collaborative skills. It can create a positive, authentic learning environment for students to increase the level of understanding and the motivation of students. Project based instruction organizes learning around projects, which are complex tasks based on authentic, challenging problems or questions that involve students in critical thinking and culminate in realistic products. It resembles problem-based learning in the use of authentic content, authentic assessment, teacher facilitation, cooperative learning, and reflection. Project based instruction is distinctive, however, in using problems that are better structured or better defined.

In project based instruction, students gain important knowledge and skills by investigating open-ended questions to make meaning that they transmit in purposeful ways. In projects, students are likely to read, research, work in teams, consult experts, use a variety of technologies, write, create media, and speak publicly in the process of the learning cycle .It is described 
as a teaching strategy that would enable students to connect knowledge, skills, values, and attitudes and construct knowledge through a variety of learning experiences .Thus, asynchronous discussion forums, chat, and other computer-mediated tools facilitate social exchanges between instructors and students during online learning. Project based instruction is used in higher education to develop students' competencies for problem solving, group work, and self-management. It involves students in generating, evaluating, and implementing project ideas. It improves communication skills, problem-solving skills, ability and willingness to learn, and teamwork (Koh, Herring and Hew, 2010, Musa, et al., 2012).

Lam, Cheng, and Choy (2010) clarify that project based instruction is part of the instructional approach originating from Dewey (1938), who stressed the importance of practical experience in learning. In project based instruction, students work in small groups on academic tasks. The task can be in the form of investigation or research on a particular topic. Students in the same small group collaborate with one another to reach a collective outcome over a period of time. They pursue solutions to a problem by asking and refining questions, debating ideas, making predictions, collecting and analyzing data, drawing conclusions, and communicating their findings to others. In addition, Thompson and Beak (2007) reported that the project provides a comprehensive approach of linking the concepts and realities and engages students in a collaborative learning activity that challenges them as both individuals and group members. It also provides numerous skill-building opportunities that maximize the value of the project.

Baúbay and Ateú (2009) indicate that project based instruction involves students in generating, evaluating, and implementing project ideas .It allows students learn by doing, applying their ideas while engaging in real-world activities through investigating questions, proposing hypotheses and explanations, discussing their ideas and finally developing solutions or outcomes . 
ÖzdamlÕ (2011) indicates that project based instruction is a model for classroom activity that shifts away from the classroom practices of short, isolated teacher-centered lessons and instead emphasizes learning activities that are long term, student-centered, and integrated with real world issues and practices. One benefit of practicing project based instruction is the unique way that it can motivate students by engaging them in their own learning. It provides opportunities for students to pursue their own interests and questions, make decisions about how they will find answers, and solve problems. In the classroom, project based instruction provides many opportunities for teachers to build relationship with students. It is a method of teaching in which students acquire new knowledge and skills in the course of designing, planning, and producing a multimedia product.

Railsback (2002) clarifies that project based instruction includes different benefits such as increasing motivation and connecting learning at school with reality that students retain more knowledge and skills when they are engaged in stimulating projects. With projects, students use higher order thinking skills rather than memorizing facts in an isolated context without a connection to how and where they are used in the real world and increase social and communication skills and self-esteem. Students take a role in accomplishing something that has value outside the classroom and providing a practical, real-world way to learn to use technology.

Therefore, learners who participate in project based instruction would be encouraged to cooperate with their group members to discuss and share opinions. Project based instruction aims to cultivate the capability of active and selfregulated learning of students who are the supporters as well as the learners in the process of interacting with teachers. Project based instruction as an excellent form of instruction encourages the self-learning of students. It could provide students with more learning chances and interpersonal interactions, as it conforms to the requirements of technological instruction. Technology- 
integrated project based instruction environment provides a real-world, constructivist, cooperative learning environment that has many advantages over the traditional project based instruction environment. It is an instructional strategy that, via participating in a project, appeals to students due to learning by way of problem solving and discussion, as well as the presentation of the results as reports. Thus, applying technology in project based instruction could support cooperative activities and constructivist approaches in learning. However, while conducting project based instruction activities in large classrooms, it is difficult to have the students concentrate on the learning tasks. Moreover, for most students, it is challenging to connect the new content with their prior knowledge (Hung, Hwang, and Huang, 2012 ,Osakue and Thomas,2011).

Bell (2010),Maulany (2013) and Thompson and Beak (2007) indicate that there are some stages of project based instruction implementation. The first is speculation in which teachers provide the choice of project topics initially based on curriculum and discuss them with the students. In this stage, teachers and students speculate possibilities that will lead to the projects smoothly. However, for the beginner or lower level students, teachers can choose the project by themselves but still consider the students' problem. The second stage is designing the project activities, referring to organizing the structure of a project activity that includes group formation, role assigning, concerning methodology decision, information source. The third is conducting the project activities in which the students work what had been planned and designed in the previous stage. At this stage, the students gather information, discuss it with their group member, consult problems encountered in their work with the teachers, and exhibit their final products that might be in form of presentation, performance, product, publication, etc. to wider community such as other classes, teachers. The last stage is evaluation referring to the assessment of activities from the participants and discussion about whether the initial aims and 
goals have been achieved, implementation of the process, and final products.

McCarthy (2010) indicates project based instruction gives contextual and meaningful learning for students ; creates optimal environment to practice speaking English; makes students actively engage in project learning; enhances the students' interest, motivation, engagement, and enjoyment; promotes social learning that can enhance collaborative skills ; gives an optimal opportunity to improve students' language skill and students engage in authentic interaction with teachers and they encourage to learn by doing.

Cusen (2013) indicated that project based instruction should maintain a focus on the project content, consist of a series of manageable tasks, progressing in complexity and structured to provide opportunities to recycle knowledge and skills; allow students to make some of their own choices throughout the project, stimulate students' interest; afford each student the opportunity to contribute equally and use their individual skills during group work; ensure all students take responsibility and are held accountable for their work; include activities which focus on form, as well as skills practice throughout the project and provide students with continuous feedback and opportunities for reflection .

Therefore, project based instruction is an approach to teaching that keeps students motivated and inspired to learn and leads to higher levels of achievement. However, students need to be actively involved for the duration of the project. It is an instructional approach that contextualizes learning by presenting learners with problems to solve or products to develop. It functions as a bridge between using English in class and using English in real life situations outside class. It does this by placing learners in situations that require authentic use of language in order to communicate. When learners work in pairs or in teams, they find they need skills to plan, organize, negotiate, make their points, and arrive at a consensus about issues such as what tasks to perform, who will be responsible for each task, and 
how information will be researched and presented. Project based instruction includes opportunities that it provides for intrinsically motivating students to learn, fostering problemsolving, and developing independent and cooperative working skills. It is also believed that project-based instruction allows students to develop critical thinking and decision-making skills and engage in in-depth learning of subject matter (Beckett,2002 Martinez,2010, Moss and Van Duzer,1998).

Chang and Lee (2010) confirm that project based instruction has proven particularly effective when combined with computer technology. Given the growing of the Internet, technology is now a major tool in project based instruction. However, although technological advances change the tools that are used in support project based instruction; they do not change its fundamental principles. Therefore, an important challenge for educators is to train teachers in not only project based instruction pedagogy but also the technology needed to implement project based instruction successfully in the classroom.

In addition, Grivaa, Semogloua and Geladaria (2010) and Lee and Kim(2013) indicate that uses of technology to facilitate project based instruction implementation can be categorized as technology-supported or multimedia technology-assisted. In technology-supported project based instruction, the technologies are often used as communication, research tools, scaffolding tools and project management tools. In multimedia technologyassisted project based instruction research, however, such technologies are often used as production tools that enable students to organize and present their research work through multimedia .Asynchronous discussion forums, chat, and other computer-mediated tools facilitate social exchanges between instructors and students during online learning.

Mohedo and Bújez (2014)clarified that project based instruction is a student centered process that meets students' needs and encourages them to become more involved in their own learning process. While, Chikita, Nyoman and Wayan 
(2013) indicated that project based instruction is combined with learning discipline to know its effect in writing course. It needs hard effort of students in learning when it is implemented. Meanwhile, writing is considered as a productive skill which is very complex. It expects the students to produce writing product. When project based instruction is implemented in writing, the students will explore knowledge to be the material in their writing. Since project based instruction is students- centered, it needs high discipline of the students in the implementation.

Poonpon (2011) clarified that project based instruction is potentially motivating, empowering and challenging to language learners, it usually results in building learners' confidence, self-esteem, and autonomy as well as improving students'language skills, content learning, and cognitive abilities .Learning becomes fruitful for learners because they exhibit their abilities to plan, manage, and accomplish projects through their content knowledge and language skills.

Moss and Van Duzer (1998) presented the basic phases found in most projects such as selecting a topic, making plans, researching, developing products, and sharing results with others .However, because project based instruction focuses on group effort, establishing a trusting, cooperative relationship before embarking on project is also necessary. Activities that engage learners in communication tasks and in peer- and selfevaluation help create the proper classroom environment. Information gap activities (where the assignment can only be completed through sharing of the different information given each learner), learner-to-learner interviews, role plays, simulations, field trips, contact assignments outside of class, and process writing with peers prepare learners for project work.

In conclusion, it can be said that, using online project based instruction has an essential role in enhancing language skills, learner motivation, improving learning performance and prompting positive changes in their roles in learning . 


\section{The practical Part of Online project based} Instruction

Language is used as a tool for communication and function as a vehicle for acquiring knowledge .These prominent characteristics (e.g., processing and making sense of knowledge, use of language as communication, learning a language via content, collaboration with peers and teachers) make project based instruction the natural language learning context, in which students have opportunities to recycle known language while focusing on topics or themes, rather than on specific language features. Language is contextualized and presented in the way that the task of language learning becomes incidental to the task of communicating with someone about topic. Placing an emphasis on communicating information, students use complex communication skills ranging from receptive skills (e.g., reading) and productive skills (e.g., writing) to processing skills (critical and creative thinking) (Thitivesa and Essien, 2013).

Kriwas (1999) cited in Fragoulis (2009) clarified the general stages that can be used for successful project implementation. They constitute a practical guide for the sequencing of project activities for teachers who want to implement projects in their classrooms as follows:-

\section{Stage 1: Speculation}

This stage includes choice of project topic and sensitization about it, aiming at arousing interest and developing a climate conductive to speculation and investigation that will lead smoothly to the research process. Topic is chosen after a dialogue among all members of the group, and the teacher.

\section{Stage 2: Designing the project activities}

This stage includes formation of groups and assigning of roles, decisions concerning methodology, sources of information, activities that will take place, and places outside the classroom that students will visit. The better organized and more analytical the structuring of the activities, the easier and faster the research will be conducted. 


\section{Stage 3: Conducting the project activities}

At this stage the groups implement the activities designed in the previous stage. Students gather information, process and categorize it. If deemed necessary, there may be intervals of information and feedback, in which students discuss issues related with cooperation among group members, problems of personal relations, and possible changes in group composition.

\section{Stage 4: Evaluation}

Evaluation refers to the assessment of the activities from participants and discussion about whether the initial aims and goals have been achieved, implementation of the process, and final products .Evaluation also entails assessment of the experience at individual and group level, identification of errors and problems, but also appraisal of the rich cognitive and experiential material gathered. Evaluation includes evaluation from others, as well as self-evaluation.

Simpson (2011) clarifies that project based instruction is a teaching method aimed at problem solving in a collaborative environment over an extended period of time. It focuses on experience which starts from driving questions or problems that create activities and leads to the meaningful products at the end. It is also a systematic instruction method that develops students; skills through valuable projects.

Thus, Cruz and Vik (2007) clarify that project based instruction activities require longer time for completion because of their complexity and interactive nature. Many instructors may find that while students may initially be disturbed during the early stages of implementation of project based instruction, as time passes students' frustrations tend to dissipate as they release their habit of waiting for step-by-step instructor-based commands and embrace their freedom to learn by doing within a team context. Therefore, several researchers conducted studies for using project based instruction in language learning as follows:- 
Grivaa, Semogloua and Geladaria (2010) outline the process of introducing a pilot early Foreign Language (FL) project conducted in a game-based context. Their study aimed at developing young learners' early English language skills through being involved in interactive simulation and physical activities. The project was coordinated in two major phases: the warm-up phase and the basic phase of the intervention carried out through three major steps: introducing the topic and demonstrating the games, playing and interacting through games and recycling new language patterns. The results from recording and evaluating the effectiveness of the intervention project indicated the positive effects of the project on children's oral skills development in FL.

Poonpon (2011) investigated learners' opinions about the implementation of project-based learning in a language classroom to encourage learners to apply their language skills and knowledge of their specific field of study to complete a task, and how project-based learning may enhance their four skills of English (i.e., listening, speaking, reading and writing). Forty-seven undergraduate students taking an English course on Information Science were required to work in groups to complete an interdisciplinary-based project. A semi-structured interview was used to elicit students' opinions about the implementation of the project and how such a project may enhance their English skills. Results of the study revealed how the interdisciplinary-based project should be implemented in a language classroom to enhance the learners' English skills.

Chikita, Nyoman and Wayan (2013) investigated the effect of Project Based Learning and students' perceived learning discipline on students' writing competency of the eleventh grade students. The participants of the study were 80 students. Data were collected by an essay type test. The acquired data were analyzed statistically by two ways ANOVA. The results of the study reveal that, there is a significant effect of project based learning on students' writing competency, there is no significant effect of the interaction between teaching methods and students' 
learning discipline level (high and low levels) on students' writing competency. Project based learning has significant effect for both high and low discipline students. Based on the analysis, project based learning has positive effect on students' writing competency.

Thitivesa and Essien (2013) explore the use of project work in a content-based instruction in a Rajabhat University, where student teachers are instructed to perform teaching roles mainly in basic education level. Its aim is to link theory to practice, and help language teachers maximize the full potential of project work for genuine communication and give real meaning to writing activity. The sample of the study comprised of 38 fourthyear English major students. The data was collected by means of achievement test, student writing works, and project diary. Project diary serves as students' record of the language acquired during the project. List of structures and vocabulary noted in the diary has shown students' ability to attend to, recognize, and focus on meaningful patterns of language forms.

Marwan (2015) reports the findings of an action research implementing project-based learning (PBL) with information and communication technology (ICT) in an English classroom. Twenty-five students from a vocational higher institution were interviewed after the conduct of three project activities over a six-week period. They were also observed while being exposed to a PBL teaching approach. Results of the study revealed that students could experience a more interesting and meaningful learning in a PBL English class. They were also becoming highly motivated to use English more intensively while exposed to this teaching approach. This research also proved that PBL with ICT could bring positive gains due to teacher's pedagogical and technological beliefs. Thus, it concludes that teaching with PBL and ICT would bring about a positive change once supported with teacher's belief about teaching and learning (pedagogical 
belief) and his belief about ICT (e.g., technology-supported learning offers better outcomes that that of the traditional one).

\section{Conclusions}

Project-based learning is a popular teaching practice built around student-driven projects, done either independently or collaboratively, that are often shared with one or more groups of students. This way, students are encouraged to learn by doing, which may lead to more interest, excitement, and energy in the classroom2

Project based instruction is a flexible methodology allowing multiple skills to be developed in an integrated, meaningful, ongoing activity. It allows instructors to teach the four English skills (listening, speaking, reading and writing) while giving both instructors and students freedom in what project they choose and how they carry it out. project based instruction is a model for classroom activity that shifts away from the usual classroom practices of short, isolated, teacher-centered lessons. Learning activities in project based instruction are long-term, student-centered, and integrated with real-world issues and practices. Project based instruction is a method that fosters abstract, intellectual tasks to explore complex issues and promote understanding, which is true knowledge. In project based instruction, students explore, make judgments, interpret, and synthesize information in meaningful ways. It is more representative of how adults are asked to learn and demonstrate knowledge. It helps students develop skills for living in a knowledge-based and highly technological society (Educational Technology Division Ministry of Education,2006, Foss,et al,2007, Vurdien,2011).

Therefore, project based instruction is designed to engage students in sustained, cooperative investigation. Within this

\footnotetext{
${ }^{2}$ http://www.lexialearning.com/blog/project-based-learning-beneficial-approachenglish-language-learners
} 
framework, students construct their own artifacts (i.e. formal report, consequential task, or PowerPoint presentation) to represent what is being learned. Using project based instruction to teach more effectively is a learner-centered approach which requires students' active participation in the construct of their own learning. Project based instruction activities tend to be complicated and challenging and require teamwork among students.

\section{References}

Alodwan,T.A.\& Ibnian,S.S.K.(2014). The Effect of Using the Process Approach to Writing on Developing University Students' Essay Writing Skills in EFL . Review of Arts and Humanities,3(2), 139-155.

Alsied, S.M. \& Pathan, M.M.(2013). The Use of Computer Technology in EFL Classroom: Advantages and Implications. International Refereed \& Indexed Journal of English Language \& Translation Studies,1(1),61-71.

Bagheri,M.S.\& Faghih,M.(2012). The Relationship between Selfesteem, Personality Type and Reading Comprehension of Iranian EFL Students. Theory and Practice in Language Studies, 2(8), 1641-1650.

Baúbay,M.\& Ateú,A.(2009). The reflections of student teachers on project based instruction and investigating self-evaluation versus teacher evaluation. Procedia Social and Behavioral Sciences 1, 242-247.

Beckett, G.H. (2002). Teacher and Student Evaluations of ProjectBased Instruction. TESL CANADA JOURNAUREVUE TESL DU CANADA 19(2), 52-66. (An online ERIC database abstract No.EJ645364).

Bell, S. (2010). Project-based learning for the 21th century: skill for the future. The Cleaning House, 83, 39-43.

Chang ,L.c,\& Lee,G.(2010). A team-teaching model for practicing project- based learning in high school:Collaboration between computer and subject teachers. Computers \& Education 55,961-969. 
Chikita, G.P. , Nyoman,N.P. \& Wayan,S.I.(2013). The effect of project based instruction and students' perceived learning discipline toward the writing competency of the eleventh grade students . e-Journal Program Pascasarjana Universitas Pendidikan Ganesha,1,1-11.

Cruz ,H.A.and Vik,G.N.(2007). Using Project-Based Learning to Connect Theory to Practice in Teaching Accounting Communication. Proceedings of the Association for Business Communication Annual Convention.

Cusen,O.M.(2013). The Child Soldiers Project: Employing a Project-Based Learning and Teaching Curriculum. Language Education in Asia,4(2),163-174

Educational Technology Division Ministry of Education(2006).

Project-based learning: handbook Educating the Millennial

Learner. Malaysia.: Educational Technology Division Ministry of Education.

Foss, P.; Carney, N.; McDonald, K. and Rooks, M. (2007). Project-

Based Learning Activities for Short-Term Intensive English Programs. Asian EFL Journal,23,1-19.

Grivaa, E., Semogloua,K. and Geladaria, A.(2010). Early foreign language learning: Implementation of a project in a game based context. Procedia Social and Behavioral Sciences 2,3,700-3705

Hung, C.-M., Hwang, G.-J., \& Huang, I. (2012). A Project-based Digital Storytelling Approach for Improving Students' Learning Motivation, Problem-Solving Competence and Learning Achievement. Educational Technology \& Society, 15 (4), 368-379.

Koh, J.H.L., Herring, S.C., \& Hew,k.F.(2010). Project-based learning and student knowledge construction during asynchronous online discussion. Internet and Higher Education 13 ,284- 291.

Krauss, J. \&Boss, S. (2013).Thinking Through Project-based Learning: Guiding Deeper Inquiry. London: SAGE Publications Ltd.

Kriwas, S. (1999) cited in Fragoulis, I (2009). Project-Based Learning in the Teaching of English as A Foreign Language 
in Greek Primary Schools: From Theory to Practice. English Language Teaching, 2(3), 113-119.

Lam, S., Cheng, R.W. \& Choy, H.C. (2010) .School support and teacher motivation to implement project-based learning .Learning and Instruction 20, 487-497.

Lee, K.J. \& Kim, J.E. (2013).mobile based learning tool to improve writing skills of EFL learners. Procedia - Social and Behavioral Sciences, 106, 112 -119.

Martinez, R. (2010). Project-based learning: an applied ethnographic case study of two secondary English language arts classrooms. Unpublished doctoral dissertation, University of Hawaii.

Marwan, A. (2015). Empowering English through Project-Based Learning with ICT. TOJET: The Turkish Online Journal of Educational Technology,14 (4),28-37.

Maulany, D.B. (2013). The use of project-based learning in improving the students'speaking skill. Journal of English and Education, 1(1), 30-42.

McCarthy,T. (2010).Integrating Project-based learning into a traditional skills-based curriculum to foster learner autonomy: An action research. The Journal of Kanda University of international studies,22,220-244.

Mills, S.C.(2006). Using the Internet for Active Teaching and Learning. Upper Saddle River,New Jersey: Pearson Education, Inc.

Mohedo, M.T.D. \& Bújez, A.V. (2014). Project based teaching as a didactic strategy for the learning and development of basic competences in future teachers. Procedia - Social and Behavioral Sciences ,141,232 - 236.

Moss, D. \& Van Duzer, C. (1998). Project-Based Learning for Adult English Language Learners. (An online ERIC database full text No. ED427556).

Musa, F.; Mufti, N.; Abdul Latiff, R. \& AminM.M. (2012). Projectbased learning (PjBL): inculcating soft skills in 21st century workplace. Procedia - Social and Behavioral Sciences 59, $565-573$. 
Osakue, E.E. \& Thomas, G. (2011). Students' Perception of Project Assisted Learning. Latin American and Caribbean Journal of Engineering Education, 5(1),12-17.

ÖzdamlÕ, F. (2011). The experiences of teacher candidates in developing instructional multimedia materials in project based instruction. Procedia Social and Behavioral Sciences $15,3810-3820$.

Poonpon,K.(2011). Enhancing English skills through projectbased learning. The English Teacher , XL, 1-10.

Railsback,J. (2002). PROJECT-BASED INSTRUCTION: Creating Excitement for Learning. Healy, AK:Northwest regional educational laboratory.

Simpson, J. (2011). Integrating Project based instructionin an English Language Tourism classroom in a Thai University. Unpublished doctoral dissertation, Australian Catholic University, Australia.

Supadol, P., Sukreeyapong, W., Intarakumhaeng, P., Siripan, K., Chantanapim, W. \&Nesusin, N. (2014). Results of Learning Activities of Grade 1 Thai Language Subjects Using the Project-Based Approach. Procedia - Social and Behavioral Sciences $116,1444-1448$.

Thitivesa,D.\& Essien,A.M.(2013). The Use of Project to Enhance Writing Skill. World Academy of Science, Engineering and Technology, 7 ,06-28.

Thompson, K.J. \& Beak, J. (2007). The Leadership Book: Enhancing the Theory-Practice Connection Through Project-Based Learning. Journal of Management Education, 31(2), 278-291.

Vurdien, R. (2011).Enhancing writing skills through blogs in an EFL class. EUROCALL, The CALL Triangle: student, teacher and institution .Available on line at (eurocall.webs.upv.es/documentos/newsletter/papers.../35_v urdien.pdf) retrieved on (11-11-2014). 
